\title{
Indicators of the antioxidant system and oxidative stress of triticale shoots under chloride salinity
}

\author{
(C) Viktor V. Ivanishchev \\ Department of Biology and Technologies of Living Systems. Tula State Lev Tolstoy Pedagogical University. \\ Lenin Ave., 125. Tula, 300026. Russia.Phone:+7 (4872)65-78-08.E-mail: avdey_VV@mail.ru
}

Keywords: triticale, shoots, chloride stress, antioxidant enzymes, oxidative stress, principal component analysis, cluster analysis.

\begin{abstract}
Alterations in the activity of antioxidant enzymes (catalase, ascorbate peroxidase, guaiacol peroxidase, glutathione reductase), the content of low molecular weight antioxidants (ascorbic acid, glutathione, and proline), as well as indicators of oxidative stress (hydrogen peroxide, superoxide radical, lipid peroxidation LPO) in the shoots of triticale (Triticosecale) under short-term $(0-96 \mathrm{~h})$ sodium chloride stress $(120 \mathrm{mM})$ were studied with statistical methods: principal component analysis (PCA) and cluster analysis. The application of the PCA method did not always lead to definite results that could be unambiguously interpreted from the point of view of modern concepts in the field of plant physiology and biochemistry. At the same time, high values of the correlation coefficients between individual indicators did not at all reflect their biochemical interdependence. The results obtained allow us to conclude that, under conditions of short-term chloride stress in triticale shoots, the more important function of proline is associated, rather, with the maintenance of osmotic pressure inside the cell than with the role of a low-molecular antioxidant. The mutual positive values of the correlation coefficients (with respect to each other) of the activity of catalase, glutathione reductase, LPO, the content of hydrogen peroxide and superoxide indicate the unidirectionality of the detected alterations, which reflect their known biochemical relationship and the need for glutathione reductase to maintain a certain redox-state in plant cells. With cluster analysis it was shown that under conditions of shortterm chloride stress in triticale shoots, the studied enzymes (catalase, ascorbate peroxidase, guaiacol peroxidase, and glutathione reductase) play a more significant role in neutralizing of reactive oxygen species, and maintaining the state of membranes, than low molecular weight antioxidants.
\end{abstract}

\section{References}

[1] V.V. Ivanishchev. About the mechanisms of plant resistance to salt and specificity of salinization influence. Proceedings of TulSU. Natural Sciences. 2019. Iss.4. P.74-88. (russian)

[2] M. Torabi. Physiological and biochemical responses of plants to salt stress. The 1st Intern Conf on New Ideas in Agricultural. Islamic Azad University Khoragsan Branch. 26-27 jan 2014. Isfahan, Iran. 2014. 25 p. https://www.semanticscholar.org/paper/PHYSIOLOGICAL-ANDBIOCHEMICAL-RESPONSESOF-PLANTS Torabi/f8867445eae6156a0e16ef13f2c74e6c836be7e9\#citing-papers.

[3] H. Jian, J. Wang, T. Wang et al. Identification of rapeseed microRNAs involved in early stage seed germination under salt and drought stresses. Frontiers in plant science. 2016. Vol.7. P.658. doi: $10.3389 /$ fpls.2016.00658

[4] V.V. Ivanishchev. The application of statistical methods to indicators of triticale photosynthesis under chloride stress. ButlerovCommunications. 2020.Vol.61. No.3. P.105-111. DOI: 10.37952/ROI-jbc-01/2061-2-3-105

[5] V.V. Ivanishchev. Application of principal component analysis to the indicators of water exchange of triticale shoots under $\mathrm{NaCl}$ stress. Butlerov Communications. 2020. Vol.62. No.4.P.129-134. DOI: 10.37952/ROI-jbc-01/20-62-4-129

[6] V.V. Ivanishchev, and N.N. Zhukov. On the interrelation of water exchange and photosynthesis in triticale sprouts with short-term action of sodium chloride. Butlerov Communications. 2018. Vol.53. No.3. P.35-42. DOI: 10.37952/ROI-jbc-01/18-53-3-35

[7] A.R. Garifzyanov, N.N. Zhukov, Yu.O. Pantyukhin, V.V. Ivanishchev. Features of NaCl-induced oxidative stress and dynamics of antioxidant enzyme activity in winter triticale organs. Reports of RAAS. 2012. Vol.2. P.9-11. (russian) 
[8] A.R. Garifzyanov, N.N. Zhukov. The effect of sodium chloride salinity on the content of ascorbateglutathione cycle components in the organs of triticale. Proceedings of TulSU. Natural Sciences. 2012. Iss.3. P.165-174. (russian)

[9] V.V. Ivanishchev. Oxidative stress and low molecular weight antioxidants in triticale shoots under chloride salinization. Butlerov Communications. 2020. Vol.62. No.6.P.125-130. DOI: 10.37952/ROI-jbc$01 / 20-62-6-125$

[10] V.V. Ivanishchev. Oxidative stress and antioxidant enzymes in triticale shoots under chloride salinization. Butlerov Communications. 2020. Vol.63. No.7.P.99-105. DOI: 10.37952/ROI-jbc-01/2063-7-99

[11] H.W. Heldt, Piechulla B. Plant Biochemistry (4 ed.). Amsterdam et al.: Academic Press is an imprint of Elsevier. 2011. 647p.

[12] G.N. Chupakhina. The system of ascorbic acid in plants: monograph. Kaliningrad: Kaliningrad. Univ. 1997. 120p. (russian)

[13] A.R. Garyfzyanov, N.N. Zhukov, V.V. Ivanishchev. Formation and physiological reactions of oxygen active forms in plant cells. Modern problems of science and education. 2011. Vol.2. 21p. https://elibrary.ru/download/elibrary_16903824_79256112.pdf. (russian)

[14] S.Kh. Orziev, Kh.E. Karabaev, T.S. Saatov. The alteration of the parameters of lipid peroxidation and the antioxidative system in the children presenting with pyo-inflammatory diseases of the middle ear. Otolaryngology Bulletin. 2014. Iss.3. P.39-40. (russian)

[15] O.S. Miroshnichenko. Biogenesis, physiological role and properties of catalase. Biopolymers and cells. 1992. Vol.8(6). P.3-25. https://core.ac.uk/download/pdf/211037952.pdf. (russian)

[16] A. Ayala, M.F. Muñoz, S. Argüelles. Lipid Peroxidation: Production, Metabolism, and Signaling Mechanisms of Malondialdehyde and 4-Hydroxy-2-Nonenal. Oxidative Medicine and Cellular Longevity. 2014. Hindawi Publishing Corporation. Vol.2014. Article ID 360438, 31p. http://dx.doi.org/10.1155/2014/360438 